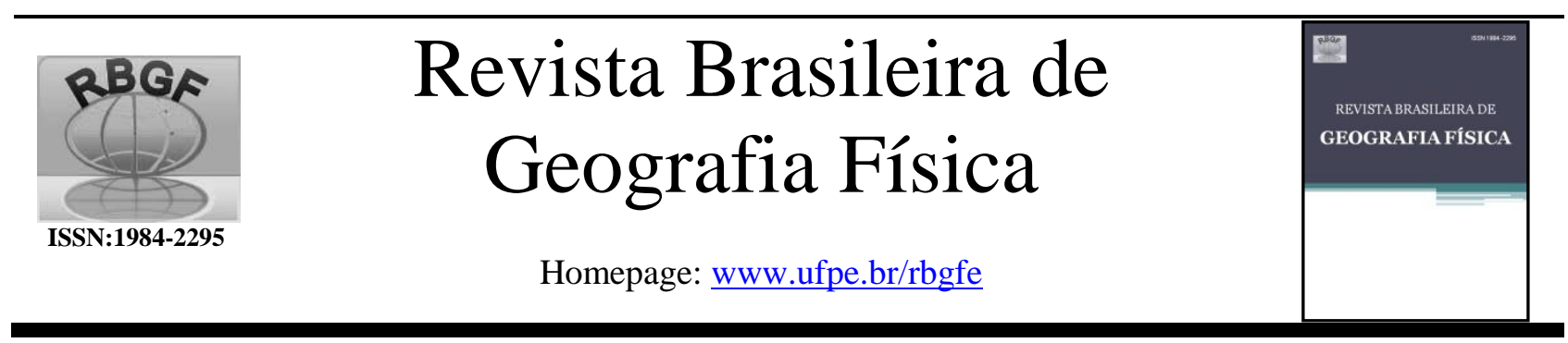

\title{
Inventário e avaliação qualitativa como subsídio à geoconservação e ao geoturismo: Litoral Sul do Estado de Pernambuco (Nordeste-Brasil)
}

\author{
Thaís Guimarães ${ }^{1}$, Gorki Mariano², Artur A. Sá ${ }^{3}$
}

\begin{abstract}
${ }^{1}$ Universidade Federal de Pernambuco, Departamento de Geologia do Centro de Tecnologia e Geociências da UFPE. Av. Prof. Moraes Rego, 1235 Cidade Universitária, Recife - PE, 50670-901. thaisguimaraes.geo@ gmail.com (autora correspondente). ${ }^{2}$ Universidade Federal de Pernambuco, Departamento de Geologia do Centro de Tecnologia e Geociências da UFPE. Av. Prof. Moraes Rego, 1235 - Cidade Universitária, Recife - PE, 50670901. gm@ufpe.br. ${ }^{3}$ Departamento de Geologia da Universidade de Trás-os-Montes e Alto Douro e Centro de Geociências da Universidade Coimbra, Quinta de Prados, 5000-801 Vila Real, Portugal. asa@utad.pt.
\end{abstract}

Artigo recebido em 27/12/2016 e aceito em 24/06/2017

\section{R E S U M O}

A configuração geológica do Litoral Sul de Pernambuco, bem como suas formas de relevo, decorre em grande parte do magmatismo ocorrido no Cretáceo, lhe conferindo uma paisagem bastante distinta das demais áreas do litoral do Estado. A diversidade geológica e suas principais ocorrências estão diretamente relacionadas com a última etapa de fragmentação do antigo mega continente Gondwana que resultou na formação dos continentes Africano e Sul-americano. Na região afloram rochas da Bacia Sedimentar de Pernambuco, rochas ígneas vulcânicas e plutônicas associadas ao magmatismo do Cretáceo e rochas neoproterzóicas do embasamento cristalino. O trabalho compreende um estudo de caso, onde foram selecionados 13 geossítios, através da metodologia de abordagem qualitativa, tendo como objetivo inicial a descrição, classificação e valoração deste patrimônio geológico, resultando em um inventário do patrimônio geológico dessa região. Trata-se de uma pesquisa classificada como exploratória e explicativa, onde os resultados foram obtidos através de trabalho de campo e pesquisa bibliográfica interdisciplinar, relativa tanto aos elementos das Geociências como das Ciências Sociais, bem como análise qualitativa dos sítios. Diante dos resultados obtidos constatou-se a grande relevância dessa área não só do ponto de vista geológico, mas a todos os valores naturais e socioculturais a ela agregados. Esta conclusão abre precedentes para uma segunda etapa de pesquisas, que compreenderá a elaboração de um diagnóstico mais completo acerca da relevância e vulnerabilidade destes sítios para que sejam futuramente estruturadas estratégias de geoconservação e desenvolvimento local, utilizando como principais ferramentas a popularização das Geociências e o fortalecimento do geoturismo na região.

Palavras-chave: análise qualitativa, geoconservação, patrimônio geológico, Pernambuco, popularização das geociências, zonas costeiras.

\section{Inventory and qualitative evaluation for geoconservation and geoturism: Southern Coast of the estate of Pernambuco (Northeastern - Brazil)}

\begin{abstract}
A B S T R A C T
The geological setting of the southern coast of Pernambuco, as well as its landforms, stems largely from the Cretaceous felsic which provides a very different landscape from the remaining areas of Pernambuco's coast. Geological diversity and its main occurrences are directly related to the last fragmentation step of the ancient continent Gondwana, which resulted the formation of the African and South American continents. In the region arise sedimentary rocks from the local Sedimentary Basin, volcanic and plutonic igneous rocks associated with Cretaceous felsic, and neoproterozoic rocks from the crystalline. This work comprises a case study, where 13 geosites were selected through a qualitative approach, with the initial goal of description, classification and valuation of their geological patrimony, resulting in an inventory of the geological heritage of the region. It comprises an exploratory and explanatory research, where the results were obtained through fieldwork and interdisciplinary bibliographical research on both Earth and Social Sciences. Eventually, it was noticed the importance of the area, not only from the geological point of view, but also from the natural and social-cultural perspective. The findings opened a second stage of research, which shall include the preparation of a full diagnosis about the importance and vulnerability of these sites to be structured in the future using geoconservation and local development strategies as a main tool for the popularization of Geosciences and strengthening of Geotourism in the region.
\end{abstract}

Keywords: qualitative analyses, geoconservation, geoheritage, Pernambuco, popularization of geosciences, coastal zone. 


\section{Introdução}

O inventário do patrimônio geológico e geomorfológico constitui a base para a implementação de quaisquer estratégias de geoconservação em um determinado território. $\mathrm{O}$ inventário viabiliza a aplicação de análises qualitativas e quantitativas dos elementos que compõem o patrimônio geológico dessas áreas, avaliando características distintas, como cientificidade, raridade, vulnerabilidade, condições de acesso e/ou potencial turístico, entre outros.

A porção sul da zona costeira do Estado de Pernambuco é dotada de relevante geodiversidade, decorrente dos processos geodinâmicos ocorridos ao longo de milhões de anos, ligados principalmente à completa fragmentação do mega continente Gondwana e consequente abertura do Oceano Atlântico Sul. Tais processos contribuíram para a configuração geomorfológica passada e atual do litoral pernambucano, que apresenta importância científica e educativa relevante, ao mesmo tempo em que se destaca esteticamente diante das demais áreas litorâneas do Estado.

Entre a geodiversidade da região, sobressaem formações geológicas e feições geomorfológicas que justificam a elaboração de um projeto futuro de geoconservação. Esse projeto teria como principal objetivo desenvolver e estabelecer um plano estratégico de desenvolvimento regional que possa contribuir para a conservação e possível garantia destas feições às gerações futuras, além de beneficiar a população, através da sua utilização como base de projetos e iniciativas de educação e valoração do território, através, por exemplo, do geoturismo, contribuindo, desse modo, para o seu desenvolvimento sustentável.

O presente trabalho tem como objetivo apresentar a inventariação do patrimônio geológico desta zona costeira objetivando no futuro, como mencionado anteriormente, a proposição de estratégias de geoconservação e base para uma possível candidatura à inclusão deste território nos Geoparques Mundiais da UNESCO. Para isso foram utilizadas três metodologias de análises qualitativas a fim de obter resultados mais objetivos.

O inventário aqui apresentado tem como base principal a relevância científica dos geossítios. Contudo, como o modelo de gestão dos geoparques propõe o desenvolvimento socioeconômico e o bem estar das pessoas, este inventário vai além dos processos geológicos e do valor científico presente na região.

No território ocorrem geossítios com valores educacionais, culturais e turísticos que, integrados em um plano estratégico de desenvolvimento e gestão, podem contribuir significativamente para melhorar a qualidade da vida das comunidades da região.

Dessa forma, foram identificados, descritos, classificados e mapeados 13 geossítios, que servirão como base para a posterior elaboração de estratégias de geoconservação e desenvolvimento socioeconômico para este território costeiro densamente povoado.

\section{Localização e contexto geológico}

A área de estudo está inserida na zona costeira sul do Estado de Pernambuco e abrange os municípios de Cabo de Santo Agostinho, Ipojuca, Sirinhaém, Rio Formoso, Tamandaré, Barreiros e São José da Coroa Grande.

Geologicamente a área está dividida em três principais grupos de rochas: $i$ ) o embasamento cristalino, com rochas neoproterozóicas, pertencentes ao Complexo Pernambuco-Alagoas; ii) rochas sedimentares cretácicas da Bacia de Pernambuco; e iii) as rochas de idade cretácica da Suíte Magmática Ipojuca, que intrudem a Bacia Sedimentar de Pernambuco em sua porção central. Sobre tais rochas encontram-se ainda em alguns pontos, sedimentos da Formação Barreiras, com idade neogênica, e depósitos quaternários (Figura $1)$.

As rochas do embasamento cristalino se tornaram alvo de pesquisas com maior intensidade há pelo menos três décadas. A área foi denominada por Brito Neves (1975) como Maciço PernambucoAlagoas, sendo posteriormente renomeado por Santos (1995) como Terreno PernambucoAlagoas. Anos depois, o termo Complexo Pernambuco-Alagoas (PEAL), foi apresentado por Silva Filho et al. (2002).

A Bacia Sedimentar de Pernambuco foi por algum tempo denominada como "Bacia Pernambuco-Paraíba", compreendendo as regiões costeiras dos estados da Paraíba, Pernambuco e da margem leste do Rio Grande do Norte. Contudo, tomando por base as diferenças estratigráficas e estruturais da Bacia Pernambuco-Paraíba, Lima Filho (1998) sugeriu a separação em duas bacias distintas. Tais diferenças contribuíram para a configuração geomorfológica atual da Bacia de Pernambuco e, consequentemente, da zona costeira Sul do Estado.

A evolução da Bacia Sedimentar de Pernambuco conta com cinco eventos tectonomagmáticos, onde o último marca a discordância do final do Turoniano (92-88 Ma), quando ocorreu a ruptura final do Gondwana, rompendo, a ligação terrestre entre o Nordeste 
oriental do Brasil e o Oeste africano (Lima Filho, 1998). Estratigraficamente, esta bacia é composta, da base para o topo, pelas formações Cabo, Suape, Paraíso, Estiva e Algodoais, com idades AptianoAlbiano (Lima Filho, 1998; Maia, 2012).

A Suíte Magmática Ipojuca compreende as rochas ígneas que intrudem a Bacia Pernambuco há aproximadamente $102 \mathrm{Ma}$. É composta por riolitos, basaltos, pelo granito do Cabo de Santo Agostinho, e por depósitos piroclásticos, ignimbritos e fluxos piroclásticos (Lima Filho, 1998).

Os componentes litológicos da suíte magmática são classificados em três grupos: $i$ ) rochas plutônicas a hipoabissais, essencialmente representadas pelo Granito do Cabo; ii) rochas vulcânicas (derrames, soleiras, plugs) que incluem basaltos, traquiandesitos, riolitos e ignimbritos; e iii) diques riolíticos, intrusivos nas demais unidades, de idade incerta (Nascimento, 2003).

No topo da sequência estratigráfica ocorrem alguns níveis de sedimentos e rochas pertencentes a Formação Barreiras. Esta unidade geológica ocorre ao longo de grande parte do litoral brasileiro e foi citada por Branner (1904). A ausência de fósseis dificulta também a identificação dos processos que originaram os depósitos como, por exemplo, a ocorrência de influência marinha. Nesses casos, Rossetti e Góes (2009) sugerem uma análise detalhada das estruturas físicas sedimentares, associadas aos estudos de icnofósseis, a fim de interpretar os processos sedimentares existentes.

Em pesquisas realizadas por Arai (2006) propõem-se quatro eventos relacionados aos sedimentos e rochas da Formação Barreiras. O primeiro corresponde a um processo de deposição do Barreiras Inferior, ocorrido durante a subida eustática entre o Aquitaniano - Serravaliano (Eomioceno a Mesomioceno). Seguida pela deposição da unidade Barreiras Superior durante o Plioceno, com a presença da Discordância Tortoniana entre ambas as unidades. $\mathrm{O}$ terceiro evento trata-se do soerguimento epirogenético, ocorrido após a queda eustática, este resultou em sua atual configuração topográfica. $\mathrm{O}$ quarto evento que teria moldado a morfologia da plataforma continental está relacionado aos processos erosivos e ao retrabalhamento, que ocorreram nos períodos de mar baixo (Tortoniano e Pleistoceno) (Arai, 2006).

Por último, em toda extensão litorânea é possível observar a cobertura de sedimentos do Quaternário, repousando sobre as unidades geológicas mais antigas. Correspondem a terraços marinhos pleistocênicos e holocênicos, sedimentos provenientes de processos fluviais, recifes de arenito, sedimentos de praia, sedimentos aluvionares e sedimentos de mangue, presentes em toda faixa litorânea, ao longo dos estuários dos rios Jaboatão, Massangana, Tatuoca, Ipojuca, Maracaípe, Sirinhaém, Formoso, Mamucabas e Una (Pfaltzgraff, 2007).

\section{Material e métodos}

Para realização deste inventário foi criado inicialmente um quadro conceitual para definir as etapas de trabalho e a abordagem metodológica, com opção de uma pesquisa descritiva associada ao estudo de caso (Miles et al., 2014). Foram também seguidas algumas ações propostas por García Cortés et al. (2014), com destaque para a definição do objetivo, escala, área e o preenchimento de fichas de catalogação utilizadas para criação do banco de dados, com todas as informações necessárias relativas aos geossítios a serem inventariados.

$\mathrm{Na}$ primeira etapa deste trabalho foi realizada uma revisão bibliográfica sistemática de diversas metodologias aplicadas à inventariação do patrimônio geológico no Brasil e em alguns países da Europa, como: Uceda, 1996; Uceda, 2000; Gray, 2004; Brilha, 2005; Pena Reis e Henriques, 2007; García Cortés, 2009; Lima et al., 2010; Fuertes-Gutiérrez e Fernández-Martínez, 2010; Pereira, 2010; García Cortés et al., 2014; Henriques e Pena Reis, 2015; Brilha, 2015; que permitiram definir as metodologias de trabalho já aplicadas ao patrimônio geológico.

Os trabalhos de campo e o conhecimento prévio da região corroboraram a seleção das metodologias. A área tomou por base, a princípio, o conceito estabelecido pelo governo federal através do Plano Nacional de Gerenciamento Costeiro (PNGC II) disposto no parágrafo único da Lei $N^{\circ} 7.661$ que define a zona costeira como "um espaço geográfico de interação do ar, do mar e da terra, incluindo seus recursos ambientais e abrangendo uma faixa marítima e outra terrestre" (BRASIL, 1988, p. 1).

Em seguida a área de trabalho foi delimitada com base na Bacia Sedimentar de Pernambuco em seu setor centro-sul, levando em consideração a diversidade litológica e geomorfológica, bem como a concentração do turismo e presença de comunidades locais, a exemplo de pescadores e demais comunidades ribeirinhas.

As visitas de campo resultaram na interpretação geológica da área, com seleção e análise descritiva dos geossítios, além da cartografia, complementada com registros fotográficos. Todos os geossítios inventariados foram visitados, com exceção do geossítio da 
Rocha Vulcânica Piroclástica do Engenho Saco, onde não é permitida a entrada. O mesmo foi descrito com base em dados e na bibliografia existente.

Durante o trabalho de campo foram preenchidas fichas de catalogação, adaptadas a partir do material utilizado pela ProGEO (Associação Europeia para a Conservação do Patrimônio Geológico) e IGME (Instituto Geológico Minero de Espanha). Contudo, foi sempre dada a devida atenção para as especificidades e generalidades da área inventariada.

O levantamento dos geossítios tem como objetivos a valoração do patrimônio geológico, geoconservação e consequentes benefícios socioeconômicos para a população através do incentivo ao geoturismo.

Para isso, após a adaptação das fichas de catalogação, foram trabalhados os valores: i) científico, ii) potencialidade de uso público (didático/turístico), iii) vulnerabilidade de risco e degradação e $i v$ ) cultural (simbólico, folclórico, histórico, arqueológico).

Com a definição dos geossítios e terminada a etapa da catalogação foi adotada a metodologia proposta por Fuertes-Gutiérrez e FernándezMartínez (2010) de enquadrar os geossítios por categorias (frameworks). Assim procedeu-se à divisão dos mesmos em três grupos: $i$ ) rochas do Embasamento Cristalino (Complexo PernambucoAlagoas), ii) rochas da Bacia Sedimentar de Pernambuco e iii) rochas da Suíte Magmática Ipojuca. A mesma proposta foi também adotada para estabelecer a tipologia dos geossítios, baseada no tamanho, forma e disposição do objeto.

Dessa forma, os geossítios foram classificados como: $i$ ) pontos: sítios de pequena dimensão e com características isoladas; ii) seções: possuem características lineares, geralmente compostos por afloramentos menores; iii) mirantes, que incluem dois elementos diferentes: uma grande área de interesse geológico e o observatório de onde essa área pode ser visualizada; $i v$ ) área: sítios de maiores dimensões, podendo incluir mais do que um tipo de interesse geológico; e $v$ ) área complexa: geossítios de grandes dimensões, compostos de vários pontos, seções, áreas e/ou mirantes.

Adicionalmente outras duas análises qualitativas também foram aplicadas aos geossítios, uma com base nos valores atribuídos por Gray (2004) e a segunda, adaptada da proposta de Pena Reis e Henriques (2009), que avalia alguns índices de conteúdos patrimoniais dos sítios. Ao todo foram utilizadas três metodologias qualitativas, analisadas pelos autores com base no conhecimento bibliográfico prévio e nas análises feitas in loco em todos os geossítios.

A busca pela associação de mais de uma metodologia visa a redução da subjetividade dos métodos, um assunto que tem sido bastante discutido entre a comunidade científica Nacional e Internacional, através de uma análise comparativa de dados.

A seleção dos geossítios foi feita com base em critérios de relevância científica, educativa, turística, cultural (tangível e intangível) e risco de degradação. Dentre os geossítios agora inventariados, seis deles (Pedras Pretas, Banho de Argila de Gaibu, Promontório do Cabo, Neck Vulcânico da Usina Ipojuca, Estuário e Várzea do Una e Arenitos Algálicos da Praia de Carneiros) estão incluídos em roteiros e excursões didáticas de escolas de primeiros e segundo graus e universidades em nível regional.

Por outro lado, dez geossítios inventariados (Pedras Pretas, Banho de Argila de Gaibu, Promontório do Cabo, Ilha Vulcânica de Santo Aleixo, Formas e Meandros do Rio Formoso, Cachoeira da Bulha, Estuário e Várzea do Una, Piscinas Naturais de Porto de Galinhas, Beachrocks de Muro Alto e Arenitos Algálicos da Praia de Carneiros) estão inclusos em roteiros turísticos oferecidos por operadoras de turismo da região e são divulgados como atrativos turísticos nas páginas eletrônicas das prefeituras municipais onde se encontram.

Neste contexto, refira-se que diversos dos geossítios constantes no inventário agora apresentado foram selecionados com base em trabalho prévio realizado por Nascimento et al. (2012) e pelo Serviço Geológico do Brasil (CPRM) como parte do projeto Geoparques do Brasil (Schobbenhaus e Silva, 2012). Esses trabalhos contemplaram uma seleção e descrição geológica de 23 lugares de interesse geológico (geossítios) localizados entre os municípios do Cabo de Santo Agostinho e Tamandaré.

Contudo, no trabalho agora apresentado efetua-se uma nova abordagem metodológica, com mudanças na classificação dos geossítios e em suas tipologias. Devido a problemas como dificuldade de acesso, falta de segurança e/ou deterioração dos geossítios previamente catalogados, houve a supressão de alguns desses pontos descritos anteriormente, a exemplo do geossítio "Conglomerado do Cabo" que, embora contemplado no projeto da CPRM, foi destruído pela construção de uma estrada.

Outro exemplo que resultou na diminuição no número de geossítios através da tipologia foi o caso da área correspondente ao granito do Cabo. No inventário anterior de Nascimento et al. (2012) 
foram descritos cinco geossítios: Praia de Gaibu, Vila de Nazaré, Pedreira Granito do Cabo, Mistura de Magmas, Dique de Riolito Tardio. Com a nova configuração, tem-se agora um geossítio, classificado dentro da tipologia "área complexa", ou seja, um geossítio de grande dimensão composto por mais de um processo ou feição relevante.
Foi neste contexto que se optou por apresentar este novo inventário, que envolve ainda uma redefinição da área de trabalho, com a extensão do município de Tamandaré e a inclusão dos municípios de Barreiros e São José da Coroa Grande, no limite sul do litoral de Pernambuco, totalizando 13 geossítios inventariados (Tabela 1).

Tabela 1. Lista dos geossítios inventariados contendo algumas de suas principais características. $($ CSA $=$ Cabo de Santo Agostinho $-\mathrm{SJCG}=$ São José da Coroa Grande - Complexo PE/AL = Complexo Pernambuco/Alagoas)

\begin{tabular}{|c|c|c|c|c|c|}
\hline $\mathbf{N}^{\mathbf{o}}$ & GEOSSÍTIO & TIPOLOGIA & $\begin{array}{l}\text { CATEGORIAS } \\
\text { (FRAMEWORKS) }\end{array}$ & MUNICÍPIO & $\begin{array}{l}\text { COORDENADAS } \\
\text { UTM 25L }\end{array}$ \\
\hline G1 & Pedras Pretas & Seção & Suíte Magmática Ipojuca & CSA & $285377 / 9081828$ \\
\hline $\mathrm{G} 2$ & Banho de Argila de Gaibu & Ponto & Bacia Sedimentar de PE & CSA & $283503 / 9081480$ \\
\hline G3 & Promontório do Cabo & Área complexa & $\begin{array}{l}\text { Suíte Magmática Ipojuca / } \\
\text { Bacia Sedimentar de PE }\end{array}$ & CSA & $285786 / 9076024$ \\
\hline G4 & Neck Vulcânico da Usina Ipojuca & Área & Suíte Magmática Ipojuca & Ipojuca & $270292 / 9071562$ \\
\hline G5 & Beachrocks de Muro Alto & Seção & Bacia Sedimentar de PE & Ipojuca & $282690 / 9068246$ \\
\hline G6 & $\begin{array}{c}\text { Rocha Vulcânica Piroclástica do } \\
\text { Engenho Saco }\end{array}$ & Área & Suíte Magmática Ipojuca & Ipojuca & 271778/9067920 \\
\hline G7 & $\begin{array}{c}\text { Piscinas Naturais de Porto de } \\
\text { Galinhas }\end{array}$ & Área & Bacia Sedimentar de PE & Ipojuca & 279951/9058706 \\
\hline G8 & Ilha Vulcânica de Santo Aleixo & Área & Suíte Magmática Ipojuca & Sirinhaém & $277412 / 9047371$ \\
\hline G9 & $\begin{array}{l}\text { Formas e Meandros do Rio } \\
\text { Formoso }\end{array}$ & Área complexa & $\begin{array}{l}\text { Bacia Sedimentar de PE / } \\
\text { Suíte Magmática Ipojuca }\end{array}$ & $\begin{array}{l}\text { Rio Formoso/ } \\
\text { Sirinhaém }\end{array}$ & 269778/9039265 \\
\hline G10 & $\begin{array}{l}\text { Arenitos Algálicos da Praia dos } \\
\text { Carneiros }\end{array}$ & Seção & Bacia Sedimentar de PE & Tamandaré & $271322 / 9037269$ \\
\hline G11 & Cachoeira da Bulha & Ponto & Complexo PE/AL & Tamandaré & $262905 / 9033610$ \\
\hline G12 & Trilha das Geoformas & Área complexa & Complexo PE/AL & Barreiros & $266166 / 9024724$ \\
\hline G13 & Estuário e Várzea do Una & Área complexa & $\begin{array}{l}\text { Bacia Sedimentar de PE / } \\
\text { Complexo PE/AL }\end{array}$ & $\begin{array}{l}\text { Barreiros / } \\
\text { SJCG }\end{array}$ & $265655 / 9020258$ \\
\hline
\end{tabular}




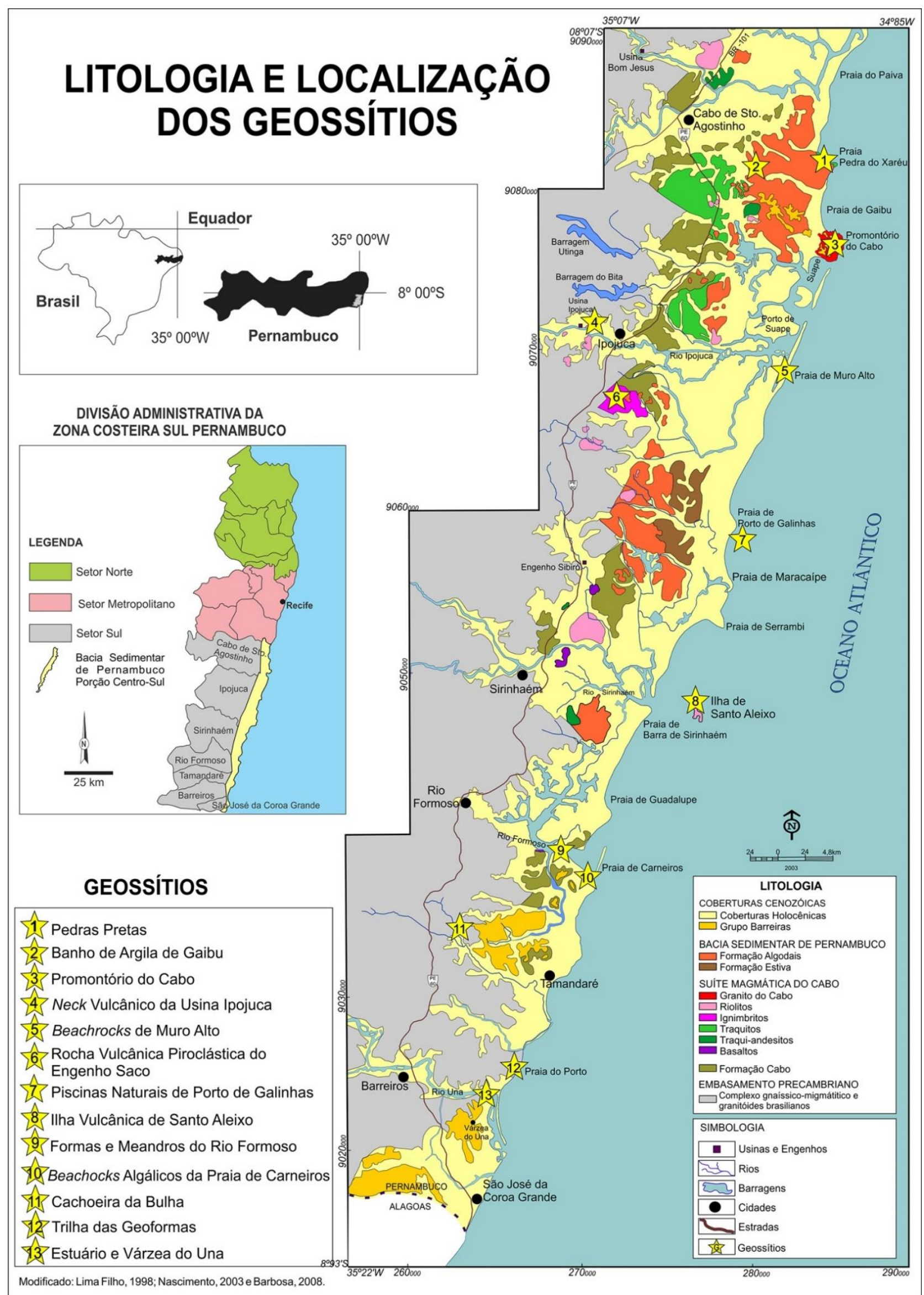

Figura 1. Localização da área, com detalhe para o mapa litológico da Bacia Sedimentar de Pernambuco e Suíte Magmática Ipojuca, área de maior concentração dos geossítios (Modificado de CPRM, 2001; Nascimento, 2004; Barbosa, 2008). 


\section{Resultados e discussão}

Patrimônio Geológico Inventariado Como citado foram inventariados, descritos e catalogados até o presente 13 geossítios, citados a seguir:

\section{G1 Pedras Pretas}

Conhecido localmente como "Pedras Pretas", este geossítio classificado como seção, corresponde a um extenso afloramento de rochas vulcânicas, com aproximadamente $4 \mathrm{~km}$ de extensão, localizado entre as praias de Itapuama e Pedra do Xaréu, no litoral do município do Cabo de Santo Agostinho (Figura 2a). Trata-se de traquitos de textura variável entre afanítica, porfirítica e vesicular, com morfologia característica de derrames (Nascimento et al., 2012). Uma peculiaridade desta ocorrência está relacionada com a coloração da rocha e nome dado localmente, uma vez que os traquitos são por natureza rochas de coloração clara (félsicas). No entanto, neste caso específico, as rochas adquiriram superficialmente uma coloração escura, resultante das ações intempéricas ao longo dos anos. Por isso são conhecidas na toponímia regional como "pedras pretas", dando nome à praia e a uma pousada-bar (Praia Pedra do Xaréu). Refira-se ainda que blocos de traquitos foram extraídos e utilizados nos calçamentos da cidade do Recife, tendo sido citada a sua utilização no ano de 1873 (MELO NETO, 1981).

\section{G2 Banho de argila de Gaibu}

Corresponde às antigas cavas originadas durante período de mineração de argila (caulim) na Formação Algodoais aflorante à noroeste de Gaibu. As argilas são produtos da alteração dos argilitos e apresentam coloração clara (branca a creme). As cavas abandonadas formam uma grande piscina, aproveitada como destino turístico para usufruto de banho de argila (Figura 2b). Este geossítio, de tipologia ponto, está inserido na Reserva Ecológica Estadual Mata de Duas Lagoas, e apresenta um bom estado de conservação. No geossítio pode-se ainda percorrer uma trilha, conhecer uma pequena produção de mel e desfruir da infraestrutura onde são vendidos produtos feitos em argila, mel, entre outros.

\section{G3 Promontório do Cabo}

Com base em suas dimensões e diversidade o geossítio foi classificado como área complexa. O promontório do Cabo de Santo Agostinho é conhecido e referenciado desde o século XVI por navegadores que desejavam encontrar as "Índias". Este não era somente o ponto mais alto da orla costeira então conhecida, mas, era essencialmente uma referência para as correntes marítimas que favoreciam a navegação nas rotas do Atlântico Sul (Figura 2c). As coordenadas geográficas que indicavam sua localização estão, por exemplo, representadas em diversos registros cartográficos do século XVI (Melo Neto et al., 1981).

No local ocorre o Granito do Cabo, com área aflorante de aproximadamente $40 \mathrm{~km}^{2}$ na costa do Atlântico a cerca de $30 \mathrm{~km}$ ao sul de Recife. Sial (1976) sugere que o granito foi formado durante a separação do mega continente Gondwana e consequente abertura do Oceano Atlântico Sul, quando uma pluma magmática ascendeu nesta região. Long et al. (1986) concluíram que o granito do Cabo foi originado a partir de fusão da crosta continental em função do calor gerado pela passagem no local da pluma de ascensão. $O$ granito é equigranular, de textura média a grossa. Em datação feita pelo método ${ }^{40} \mathrm{Ar} /{ }^{39} \mathrm{Ar}$ apresentou idade de 101,6 $\pm 1,3 \mathrm{Ma}$, a partir de traços de fissão em zircão revelou idade de $98 \pm 1$ Ma. A combinação destes dois métodos permitiu sugerir uma idade aproximada de 102 Ma para este granito (Nascimento, 2003).

Neste local regista-se ainda a ocorrência de riolito, em forma de diques intrudindo o granito. As intrusões possuem aproximadamente $1,20 \mathrm{~m}$ de largura e apresentam uma coloração castanhoamarelada distintiva. Atualmente sobre o promontório ocorrem vários processos geomorfológicos ativos, por exemplo, a erosão do tipo esfoliação esferoidal em blocos graníticos, a formação de crostas lateríticas, provenientes da lixiviação, e processos de limonitização.

No granito são identificados ainda todos os estágios de alteração, desde a rocha fresca, aos estágios inicias de alteração dos minerais e a decomposição total, onde a rocha é transformada no manto de intemperismo. Sobre estas rochas foram construídas algumas das mais importantes edificações entre os séculos XVI e XIX, em sua maior parte com blocos do próprio granito (Figura $2 d)$.

\section{G4 Neck Vulcânico da Usina Ipojuca \\ $\mathrm{O}$ geossítio foi classificado quanto à} tipologia como área. $\mathrm{O}$ afloramento foi denominado na literatura como "neck vulcânico de Ipojuca", acredita-se ser parte de um vulcão extinto do cretácico. O riolito ocorre em forma de plug vulcânico. Em sua composição mineralógica apresenta quartzo, sanidina, biotita e minerais de óxido de ferro. Exibe disjunções colunares pseudohexagonais e sub horizontais formadas pela contração e perda de volume durante o resfriamento do magma, que apresentam linhas de 
fluxo magmático (Figura 2e-f) (Nascimento et al., 2012; Lima Filho, 1998).

$\mathrm{O}$ afloramento esta inserido nas terras da centenária Usina Ipojuca, margeado pelo rio Ipojuca e por plantações de cana-de-açúcar cultivadas sobre o relevo definido como domínio dos "mares de morros", colinas baixas em formato mamelonar (Ab'Saber, 2003).

\section{G5 Beachrocks de Muro Alto}

Com base em suas formas, foi classificado quanto à tipologia como geossítio seção. Os arenitos de praia representam um importante registro holocênico das oscilações do nível do mar não só em Pernambuco, mas em todas as regiões de ocorrência (Ottmann 1960; Mabessone 1964; Suguio et al., 1985, 2013; Mauz et al., 2015; Guimarães et al., 2016).

Afloramentos localizados em Recife, mais precisamente entre a foz dos rios Beberibe e Capibaribe e as praias de Boa Viagem e Pina, foram apresentados por Barreto et al. (2010) como uma proposta de sítio geológico ao Comissão Brasileira de Sítios Geológicos e Paleobiológicos SIGEP ( $\mathrm{N}^{\mathrm{o}}$ 40), contendo além da descrição geológica e histórica dos sítios, sugestões de medidas educativas e de conservação. Guimarães et al. (2016) também destacam a importância dos arenitos e correlacionam sua importância geológica, histórica e cultural no Litoral Sul de Pernambuco.

Estas rochas são conhecidas na literatura como arrecifes ou beachrocks. Os "recifes de muro alto" como são conhecidos na toponímia regional ocorrem de forma linear com aproximadamente 4,5 km de extensão, paralelo a linha de costa (Figura $2 \mathrm{~g}$ ). Seu posicionamento, bem como os processos associados à morfologia da praia e a desembocadura do rio Ipojuca, permitem que se tenha nesta área uma enorme piscina natural, protegida das ondas e de temperatura amena.

G6 Rocha Vulcânica Piroclástica do Engenho Saco Geossítio caraterizado pela ocorrência de ignimbritos decorrentes de fluxos piroclásticos registrados como único vulcanismo explosivo de idade cretácica no Brasil. Foi classificado quanto a tipologia como geossítio área. Ocorrem em forma de derrames, exibem uma matriz fina, de cor cinza, com vários fragmentos de minerais (quartzo e Kfeldspato) e rochas dos três grandes grupos: ígneas (granitos, riolitos e traquitos), sedimentares (carbonáticas) e metamórficas (xistos e gnaisses) (Lima Filho 1998; Nascimento et al., 2009, 2012).

O afloramento está localizado em uma propriedade privada onde funciona uma pedreira que extrai a rocha para indústria de cimento (Figura 3a). O acesso até o ignimbrito é proíbido, inclusive para fins científicos. Entretanto, foi cadastrado na lista de sítios geológicos da SIGEP (Sítio n ${ }^{\circ} 103$ ).

Trata-se de um geossítio essencialmente de cunho científico e foi incluído neste inventário justamente devido à sua relevância científica, como único exemplar deste tipo de rocha piroclástica no Brasil que se tem conhecimento (Figura 3a).

\section{G7 Piscinas Naturais de Porto de Galinhas}

A praia de Porto de Galinhas é o destino turístico mais disputado no litoral sul de Pernambuco e suas piscinas naturais formadas pelos arenitos de praia são conhecidas internacionalmente. A ocorrência dos beachrocks (arenitos de praia) em Porto de Galinhas não apresenta a linearidade comum a essas rochas e ocorrem de tal forma que, em períodos de maré baixa transformam-se em atrativas piscinas naturais, com águas mornas e diversa fauna marinha (Figura 3b). De acordo com a classificação tipológica, foi classificado como geossítio área. Um equívoco cometido por boa parte da população é achar que todos os recifes na região são "recifes de corais" (BRANNER, 1904). Sabe-se que são rochas compostas em maior parte por quartzo e fragmentos de organismos, ligadas por cimento carbonático. No entanto, nesta ocorrência em Porto de Galinhas há presença dos corais dispostos sobre os arenitos como diferencial.

\section{G8 Ilha de Santo Aleixo}

Encontra-se a aproximadamente $2 \mathrm{~km}$ da costa, partindo da vila de pescadores de Barra de Sirinhaém, próximo à foz do Rio Sirinhaém. Tratase de um geossítio de tipologia área. A ilha é de propriedade privada, entretanto, há área para visitação e é comum, principalmente nos fins de semana, o aluguel de barcos por turistas para passar o dia na ilha (Figura 3c). Geologicamente foram descritos como riolitos, apresentando cristais de quartos e raros cristais de opacos e biotita, que devido à textura muito fina só podem ser observados através de microscópio petrográfico. Lima Filho (1998) descreveu os riolitos como rochas mais ácidas, de coloração acinzentada, com a ocorrência de juntas colunares sextavadas e intensamente fraturadas, apresentando normalmente uma capa delgada de intemperismo. A idade é de ${ }^{40} \mathrm{Ar} /{ }^{39} \mathrm{Ar}$ de 100 milhões de anos, mostrando certa contemporaneidade às demais rochas da Suíte Magmática Ipojuca (Nascimento et al., 2012). 

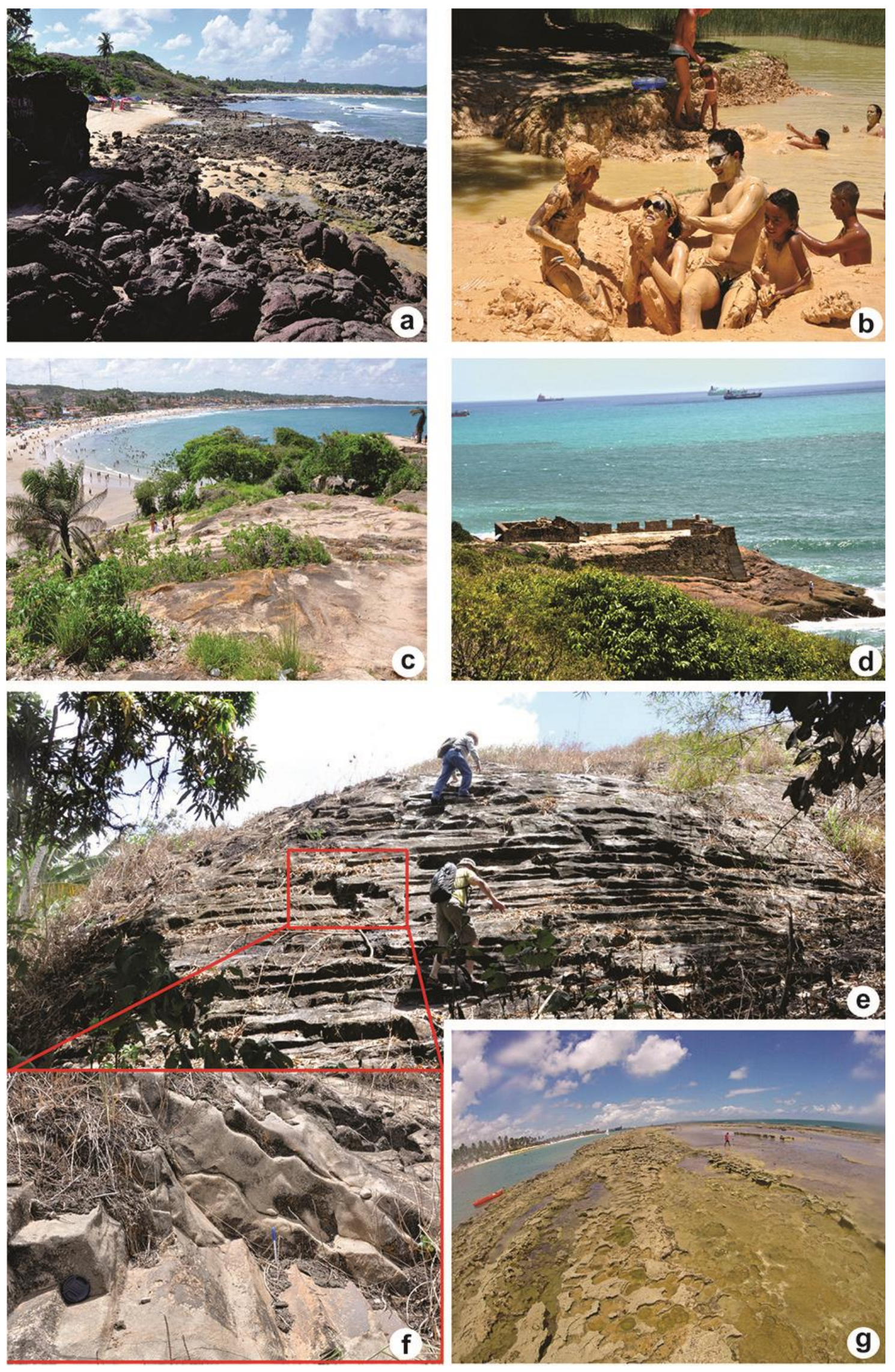

Figura 2. (a) Afloramento de traquitos, geossítio das Pedras Pretas (b) Banho de Argila de Gaibu (c) Vista do Promontório do Cabo para praia de Gaibu. (d) Imagem das ruínas do Forte Castelo do Mar - Séc. XVII, construído sobre o Granito do Cabo (e-f). Neck vulcânico da Usina Ipojuca, com detalhe para as disjunções colunares horizontais (g) Beachrocks da Praia de Muro alto. 
G9 Formas e Meandros do Rio Formoso

Localiza-se no estuário do rio Formoso, a partir da confluência com o Rio Ariquindá, o acesso aos principais pontos do geossítio é feito por barco, mas também há estradas vicinais que chegam até os principais pontos: o mirante do reduto (cruzeiro do reduto) e o banho de argila na praia fluvial à margem norte do rio (Figura 3d-e). Foi classificado como área complexa devido a sua dimensão e diversidade de processos.

O geossítio faz parte dos pacotes turísticos vendidos, onde nos passeios de barco está incluso o "banho de argila". O banho localiza-se as margens do Rio e sopé de uma falésia viva com aproximadamente 6 a 8 metros de altura. $\mathrm{O}$ geossítio está inserido na fácie distal na Formação Cabo, que foi dividida em três fácies: proximal, mediana e distal. Esta fácies é formada por subfácieis onde foi identificado um arenito fino, intercalado com estratos argilosos depositados de forma cíclica (ritmitos) e folhelhos. Os ritmitos apresentam-se bastante bioturbados. Sobre eles ocorrem níveis de arenitos finos, fração entre silte a areia muito fina, de coloração branca a creme.

Ainda foi identificada uma camada espessa de arenito fino a médio, com ocorrência de argilas esverdeadas, que sob intemperismo intenso alteram para coloração vermelha (Lima Filho, 1998; Nascimento et al, 2012).

O mirante do reduto está localizado no lado sul das margens do Rio Formoso, próximo à confluência com o rio Ariquindá, está inserido na APA de Guadalupe - Área de Preservação Ambiental do Estado. Geologicamente está inserido na Formação Cabo, é formado por arenitos conglomeráticos, intercalados com siltitos argilosos e matriz argilosa de coloração variando entre branca e verde. Há sedimentos do embasamento cristalino e derrames de traquitos ambos sob avançada ação do intemperismo. Após datação pelo método de traço de fissão em zircão, apresentou idade de 101 milhões de anos, contemporâneo aos traquitos da Praia de Pedra do Xaréu e Itapuama, já descritos neste trabalho (Lima Filho, 1998; Nascimento et al., 2012).

\section{G10 Arenitos Algálicos da Praia de Carneiros}

$\mathrm{O}$ afloramento apresenta morfologia linear em grande parte da ocorrência e foi classificado como geossítio do tipo seção. Está localizado na área de influência da desembocadura do Rio Formoso (Figura 3f-g).

Comum por sua linearidade, o diferencial deste geossítio está em sua composição. Esses arenitos foram estudados por Neumman et al. (2013) que descreveram em sua composição a presença de algas do gênero Halimeda. Os autores op cit. diferenciaram os arenitos entre os "beachrocks típicos" e os algálicos denominados em seu trabalho por "beachrocks Halimeda".

Em sua composição foi observada níveis de arenitos com predomínio de grãos de quartzo e em quantidade inferior à ocorrência de grãos de feldspatos, minerais acessórios e fragmentos de conchas. Os grãos de quartzo e feldspatos se apresentam de arredondados a subarredondados, bastante polidos, sugerindo transporte em meio subaquático. Nos níveis de Halimeda há presença de outros organismos marinhos, por exemplo, os corais (Neumann et al., 2013).

\section{G11 Cachoeira da Bulha}

O geossítio foi classificado quanto à tipologia como ponto. Faz parte do roteiro turístico local e é oferecido como produto em algumas pousadas e sites do município. A queda de água está inserida em área de preservação do bioma Mata Atlântica, nos limites da Reserva Biológica de Saltinho, e o acesso se dá a partir da rodovia PE076, no sentido do município de Tamandaré. A cachoeira se encontra do lado esquerdo da rodovia, a menos de $2 \mathrm{~km}$ após o início. A cachoeira possui aproximadamente entre 09 e $10 \mathrm{~m}$ de altura, ocorrendo em ortognaisses neoproterozoicos do embasamento cristalino e pertencentes ao Terreno Pernambuco-Alagoas, inserido na porção leste da Província da Borborema (Figura 4a).

\section{G12 Trilha das Geoformas}

Está localizada em um trecho de aproximadamente $1 \mathrm{~km}$ situado na praia do Porto (Barreiros) e tem vários acessos. A partir de Tamandaré através da estrada que corta a Reserva Ecológica Carijó $(5 \mathrm{~km})$, ou de jangada pela foz do Rio Una, partindo do distrito da Várzea do Una (São José da Coroa Grande), onde, em seguida, pode ser feito via beira mar caminhando até a Ilha do Coqueiro Solitário, um afloramento granítico pertencente a mesma litologia das demais feições que, em períodos de maré cheia forma uma pequena ilha há poucos metros da costa e com a baixa maré permite o acesso a pé (Figura $4 b$ ). $O$ geossítio foi classificado como área complexa, em virtude de sua dimensão e diversidade de processos.

As formas geomorfológicas (geoformas) são decorrentes de processos de intemperismo e erosão no granito, resultando em feições bastante curiosas, como a "pedra fatia de bolo", "pedra casco de tartaruga", "pedra da preguiça gigante", "pedra peixe-boi" ou "dorso da baleia", entre outras (Figura 4c-d). Observa-se ainda uma furna, resultante do colapso de blocos. A rocha compreende parte do embasamento cristalino, 
pertencente à suíte calcialcalina de médio a alto potássio do tipo Itaporanga, caracterizada por granitos a granodioritos grossos a porfiríticos, associado a um diorito denominado por Barbosa (2009) como Plúton Rio Formoso, com idade U-Pb aproximada de $588 \mathrm{Ma}$ (CPRM, 2005).

Em algumas das geoformas, como na pedra dorso da baleia, observa-se a ocorrência de caneluras, feições de erosão diferencial representadas por sulcos verticalizados. No granito ainda são observadas intrusões máficas menos resistentes que a rocha encaixante, favorecendo o intemperismo e, mais uma vez, a erosão diferencial.

\section{G13 Estuário e Várzea do Una}

O geossítio abrange a porção mais a jusante do baixo rio Una, entre os municípios de Barreiros e São José da Coroa Grande e foi classificado como área complexa. (Figura 4e). A comunidade mais próxima é o distrito da Várzea do Una. O acesso pode ser feito pelo rio através de passeios em pequenas jangadas que partem da comunidade do Una, ou por terra, a partir da praia do porto em Barreiros.

O rio está inserido na bacia hidrográfica do Una, associada à bacia GL5, de pequenos rios litorâneos. Na desembocadura do Rio Una formase um extenso istmo ou pontal, representado por uma longa faixa de sedimentos, com aproximadamente $4 \mathrm{~km}$ de extensão, abrangendo os municípios de Barreiros e São José da Coroa Grande. Sobressai ainda na paisagem a "Pedra Alta", afloramento de rocha granítica pertencente a suíte calcialcalina alto potássio Itaporanga, correspondendo a um granito e granodiorito porfirítico associado à diorito com idade $\mathrm{U}-\mathrm{Pb}$ aproximada de 588 Ma (CPRM, 2005). Este afloramento possui aproximadamente $70 \mathrm{~m}$ de altura, no topo apresenta gnamas, processos de intemperismo diferencial, enclaves máficos e inúmeras caneluras.

Do ponto de vista da cultura local, o afloramento, também denominado de "Pedra Encantada", envolve muitas lendas de pescadores, associadas inclusive às feições resultantes dos processos erosivos, como as cavidades decorrentes do intemperismo diferencial aonde algumas são associadas a "pegadas deixadas nas pedras".

Destacam-se ainda algumas geoformas, a exemplo da "Pedra do Sapo" e "Pedra da Coroa de Frade" (Figura 4f-g). A povoação de Várzea do Una nasceu a partir de uma vila de pescadores e possui tradição na construção de barcos de pesca, feitos em um pequeno estaleiro passado de pai para filho, o estaleiro do Mestre Zuza. A pesca artesanal ainda é atividade presente na região, desde a pesca no rio e no mar a cata do caranguejo nos manguezais, sendo comum enquanto se passeia pelo rio ou pela praia ver os pescadores em atividade.

\section{Classificação dos Geossítios}

Como já citado na metodologia, após uma exaustiva revisão bibliográfica e trabalho de campo foram definidos 13 geossítios. Com essas informações foi montado um banco de dados, a partir das fichas adaptadas da ProGEO e Instituto Geológico e Mineiro da Espanha. As fichas foram preenchidas com base em quatro valores: científico, uso público (didático e turístico), vulnerabilidade de risco/degradação e cultural (simbólico). Com base nesses dados e a partir das bibliografias consultadas foram selecionados três modelos de propostas qualitativas, a fim de se complementarem e diminuírem a subjetividade das análises.

\section{Tipologia}

A tipologia proposta por Fuertes-Gutiérrez e Fernández-Martínez (2010) apresenta uma classificação a partir do tamanho e da complexidade de elementos e valores adicionados aos geossítios. De acordo com a análise, dos 13 geossítios inventariados dois deles foram classificados como "ponto" (geossítio Banho de Argila de Gaibu e Cachoeira da Bulha). Três deles, em decorrência de sua linearidade e a composição de pequenos afloramentos em conjunto, foram classificados como "seção". Os geossítios que se enquadraram nessa tipologia estão associados aos arenitos de praia (Beachrocks de Muro Alto e Arenitos Algálicos de Praia dos Carneiros) e ao afloramento vulcânico de traquitos (Pedras Pretas).

Os geossítios incluídos na categoria "área" possuem maior extensão que os enquadrados em categoria "ponto", podendo ser tão grandes quanto às "áreas complexas", embora não apresentem a diversidade litológica ou de processos geomorfológicos destas últimas. Foram incluídos nesta categoria os geossítios Neck Vulcânico da Usina Ipojuca, Piscinas Naturais de Porto de Galinhas, Rochas Vulcânicas Piroclásticas do Engenho Saco e Ilha Vulcânica de Santo Aleixo. 

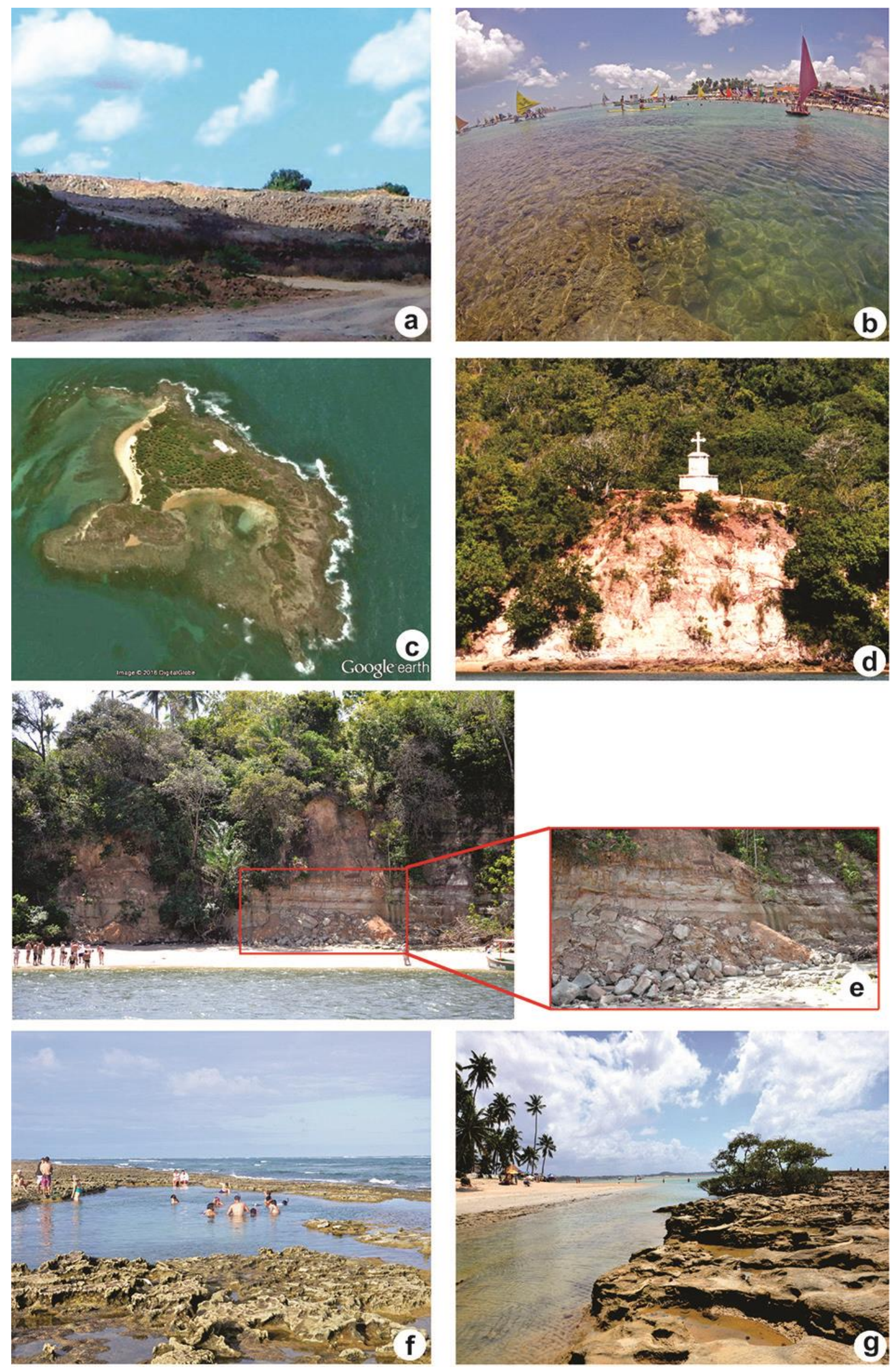

Figura 3. (a) Afloramento do Ignimbrito (Fonte: Rodrigo tavares) (b) Praia de Porto de Galinhas. (c) Ilha de Santo Aleixo (Fonte: Google Earth). (d) Mirante do Reduto (e) Falésias do Rio Formoso. (f-g) Arenitos da Praia de Carneiros. 

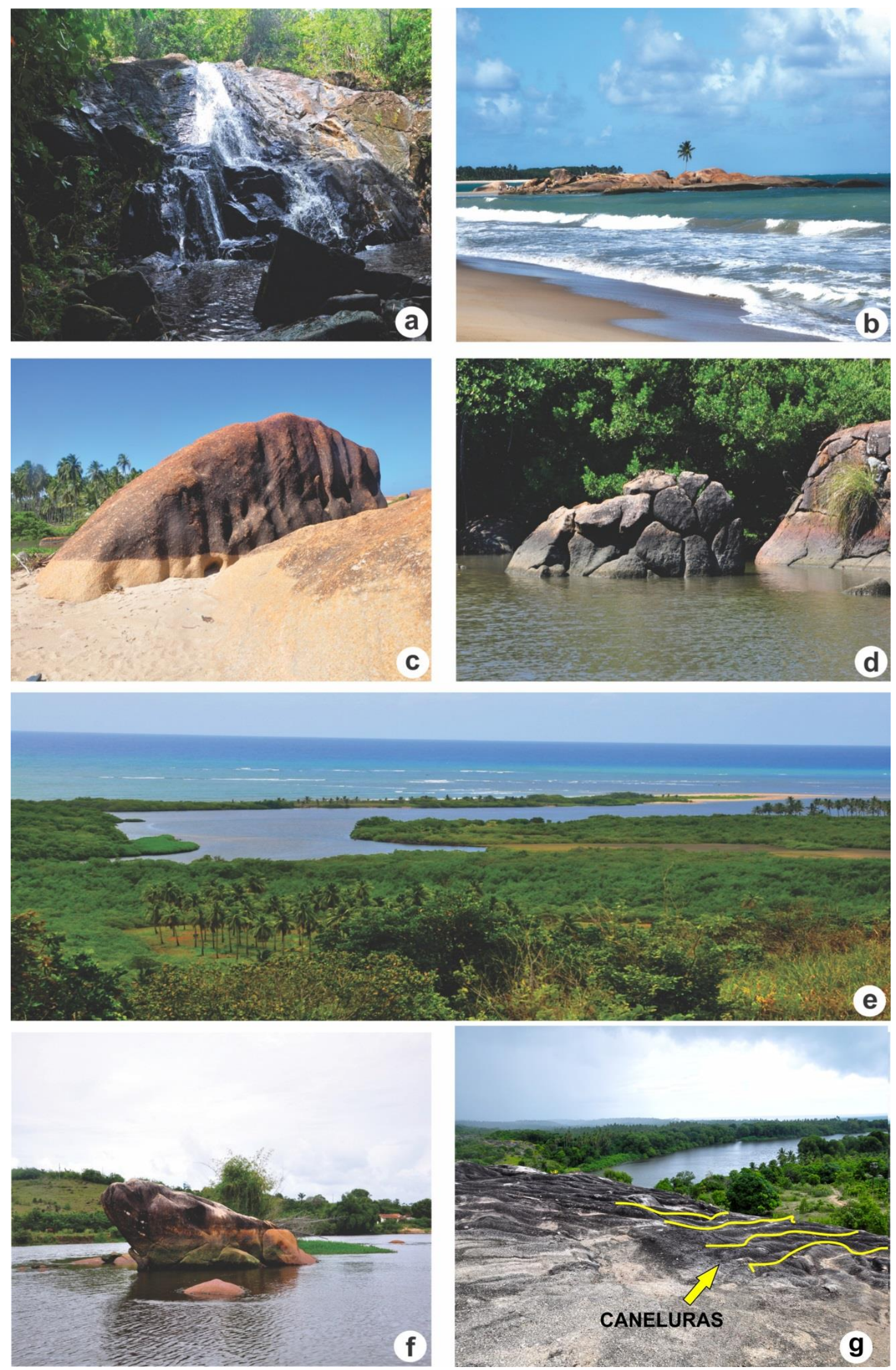

Figura 3. (a) Cachoeira da Bulha (b) Ilha do Coqueiro Solitário (c) Geoforma Dorso de Baleia (d) Geoforma Casco de Tartaruga (e) Vista panorâmica da Foz do Rio Una localizado no distrito da Várzea do Una (f) Geoforma Pedra do Sapo, vista a partir dos passeios de jangada (g) Vista a partir da Pedra Grande, próximo a Foz do Rio Una - as linhas pontilhadas indicam as inúmeras caneluras. 
Os demais geossítios foram classificados como área complexa, de acordo com seu tamanho e diversidade de elementos (Tabela 3). As áreas complexas apresentam litologias diferentes, geomorfologia diversa, bem como contínuos e visíveis processos geológicos, principalmente nos geossítios formados por rios (geossítios Formas e Meandros do Rio Formoso e Estuário e Várzea do Una) que estão sob constante influência das marés e sujeitos a consequentes modificações na paisagem. Destaca-se ainda nessa categoria o geossítio Trilha das Geoformas, formado pelo caos de blocos graníticos distribuídos na faixa de areia que vai desde a Praia do Porto (Barreiros) a Praia da Várzea do Una (São José da Coroa Grande) e o geossítio Promontório do Cabo, considerado como o geossítio de maior complexidade e diversidade analisado neste inventário.

\section{Conteúdos Patrimoniais}

A aplicação da análise qualitativa de conteúdos apresentada por Pena Reis e Henriques (2009) se configura como um sistema de avaliação aberto, aplicável a todos os geossítios, integrando não só as propriedades geológicas dos mesmos, mas também atributos relacionados com a sua utilização social.

Trata-se de um sistema de avaliação que permite o reconhecimento de diferentes conteúdos num mesmo geossítio, o que incrementa o seu valor patrimonial, bem como prioriza a implantação de medidas de geoconservação, de acordo com as categorias de maior valor, a exemplo dos geossítios com conteúdo documental (científico) e cênico (Pena Reis e Henriques, 2009; Henriques et al., 2013; Haag e Henriques, 2014). É importante ressaltar o significado de cada conteúdo e para isso foi feita uma breve descrição com base em Pena Reis e Henriques (2009) (Tabela 2).

Com a análise dos conteúdos patrimoniais obteve-se a classificação dos geossítios a partir de uma escala de grau de relevância local, regional ou global e a percepção abstrata (material, demonstrativa, cognitiva e social), adotando como parâmetros o conteúdo indicial, icnográfico, documental, simbólico, cênico e conceitual (Tabela 3). Cada um dos treze geossítios foi analisado com base nos conteúdos supracitados e após análises de campo (in loco) e pesquisas bibliográficas chegouse aos seguintes resultados:

O geossítio Pedras Pretas apresenta valor indicial, uma vez que existem processos de relevância local fáceis de serem associados, como por exemplo, as cavidades erosivas ocasionadas pelo intemperismo químico-biológico dos ouriçosdo-mar (Echinometra lucunter), que podem ser facilmente associadas a estes animais. Não apresenta valor iconográfico, contudo, possui alto valor simbólico sendo usufruído socialmente pela população local e visitante para o lazer e recreação. Apresenta valor documental, contendo informações relevantes para se compreender a evolução geológica regional. O conteúdo cênico também está presente, pois apresentam aspectos geomorfológicos de grande valor estético. Apresenta o conteúdo conceitual uma vez que a área esta diretamente associada ao estágio final da ruptura do mega continente Gondwana.

O geossítio Banho de Argila de Gaibu apresenta o conteúdo simbólico, pois possui outros atrativos além dos elementos geológicos e o conteúdo documental, uma vez que o geossítio está inserido na bacia sedimentar de Pernambuco, objeto de estudos de muitos pesquisadores da região, com inúmeras publicações nacionais e internacionais.

O geossítio Promontório do Cabo foi classificado na metodologia anterior como área complexa, pois apresenta grande diversidade de processos geológicos e feições geomorfológicas.

No que se refere aos conteúdos patrimoniais apresenta praticamente todos os conteúdos, com exceção ao conteúdo icnográfico. Trata-se de um geossítio que apresenta feições e estruturas fáceis de serem compreendidas (conteúdo indicial). O uso por moradores e visitantes vai além de seus elementos geológicos, pois apresenta importantes elementos históricos, arqueológicos, culturais e opções de lazer e recreação (conteúdo simbólico). Apresenta ainda registros indicativos de mudanças geológicas e corresponde a um plúton (intrusão magmática) intrudido na Bacia Sedimentar de Pernambuco, bastante estudada por pesquisadores na região (conteúdo documental). O geossítio destaca-se por sua beleza cênica (conteúdo cênico) e relevância global, uma vez que inserido na Suíte Magmática de Ipojuca, está associado ao último estágio de separação do mega continente Gondwana e abertura total do Oceano Atlântico Sul, eventos geológicos de relevância global.

O geossítio Neck Vulcânico da Usina Ipojuca apresenta o conteúdo indicial, representado pelas disjunções colunares e marcas de fluxo de magma, feições importantes para ilustrar aspetos e detalhes do processo geológico pretérito. Foi identificado o valor simbólico uma vez que há valores científicos ou geoturísticos associados, com ênfase em um turismo mais científico. Há ainda o conteúdo documental (publicações nacionais e internacionais relevantes), cênico se considerado o geossítio como área, incluindo não apenas o afloramento, mas também a paisagem envolvente. O conteúdo conceitual assim como os 
demais geossítios pertencentes a Suíte Magmática de Ipojuca está associada ao último estágio da separação do mega contente Gondwana.

No geossítio Beachrocks de Muro Alto, assim como nos demais, formados pelos arenitos de praia (beachrocks), - Piscinas Naturais de Porto de Galinhas e os Arenitos Algálicos da Praia de Carneiros - foi identificado o conteúdo indicial, observado, por exemplo, nas estratificações preservadas nas rochas e nas microformas de relevo; o conteúdo simbólico, uma vez que os geossítios são utilizados por moradores e turistas para o lazer e recreação; o conteúdo documental, justificado pela importância científica, através da representação dos arenitos como indicadores de oscilações no nível do mar durante o Holoceno, e o conteúdo cênico, representado pela beleza e harmonia entre os cordões de arenitos e o mar.

A visita ao geossítio da Rocha Vulcânica Piroclástica do Engenho Saco não foi possível. Contudo, ao analisar as amostras do ignimbrito, rocha predominante no geossítio, as bibliografias consultadas e fotografias do afloramento e da pedreira, é possível identificar o conteúdo indicial a partir das estruturas que compõem a rocha, como fragmentos de riolito, fiammes e vesículas que indicam ocorrência de vulcanismo explosivo. O conteúdo simbólico estaria associado às atividades educativas que poderiam ser desenvolvidas no caso de a pedreira se tornar acessível ao público, embora no estado atual este conteúdo não possa ser considerado. Não apresenta conteúdo cênico. Apresenta ainda valor documental e conceitual.

Tabela 2. Tipos de conteúdos patrimoniais propostos por Pena dos Reis e Henriques (2009)

\begin{tabular}{|c|c|}
\hline $\begin{array}{c}\text { CONTEÚDOS } \\
\text { PATRIMONIAIS }\end{array}$ & BREVE DESCRIÇÃO \\
\hline Indicial & $\begin{array}{l}\text { Atribuído a objetos geológicos que, ao expressarem uma clara relação entre determinado } \\
\text { processo geológico e os produtos daí resultantes, configuram um testemunho graficamente muito } \\
\text { expressivo do fenómeno geológico que representam. São muito utilizados sob a forma de } \\
\text { estampas em publicações científicas e em manuais de caráter didático. Trata-se de um conteúdo } \\
\text { de relevância local, importante para ilustrar aspetos de pormenor de sistemas geológicos antigos. } \\
\text { Exemplo: as conservações excepcionais de fósseis e algumas estruturas sedimentares (marcas de } \\
\text { ondas, por exemplo), cujo grafismo sugere sua origem de forma muito óbvia. }\end{array}$ \\
\hline Iconográfico & $\begin{array}{l}\text { Atribuído a objetos geológicos que traduzem uma relação clara, sob a forma de um "momento } \\
\text { instantâneo", entre determinado evento geológico, cuja interpretação requer conhecimento } \\
\text { geológico profundo, e as suas consequências. Exemplo: as pegadas de dinossauros ou as crateras } \\
\text { resultantes do impacto de meteoritos, estruturas geológicas que estimulam o imaginário dos } \\
\text { leigos, por serem facilmente interpretadas. Trata-se de um conteúdo de relevância local e } \\
\text { correspondem a uma visão muito particular e restrita da compreensão pública das geociências, } \\
\text { geralmente limitada a contextos catastróficos e/ou exóticos. }\end{array}$ \\
\hline Simbólico & $\begin{array}{l}\text { Atribuído a objetos geológicos que são intensamente usufruídos pelo público devido a outras } \\
\text { razões que não as características geológicas que se lhes reconhecem. Trata-se de um conteúdo } \\
\text { de relevância local, normalmente com elevado valor paisagístico, podendo ainda possuir outras } \\
\text { características que atraiam o público, como valores históricos, arqueológicos e geográficos. }\end{array}$ \\
\hline Documental & $\begin{array}{l}\text { Atribuído a objetos geológicos que correspondem a um registro altamente demonstrativo e } \\
\text { particularmente relevante para compreensão das mudanças geológicas ocorridas numa } \\
\text { determinada área (bacia sedimentar, por exemplo), sendo, por isso, um conteúdo de relevância } \\
\text { regional. As comunidades científicas tendem geralmente a supervalorizar estes conteúdos, que } \\
\text { constituem o foco para investigações de carácter disciplinar. }\end{array}$ \\
\hline Cênico & $\begin{array}{l}\text { Conteúdo de relevância regional atribuído a objetos geológicos que expressam uma conjugação } \\
\text { harmoniosa entre a ocupação antrópica e a conservação da natureza. Tratam-se de lugares que } \\
\text { exibem aspectos geomorfológicos de grande valor estético e que proporcionam funções } \\
\text { recreativas a elevado número de visitantes. Muitos parques naturais de renome internacional } \\
\text { tipificam este conteúdo, tal como o Parque Natural do Grand Canyon (EUA) ou o Parque } \\
\text { Nacional do Iguaçu (Brasil). }\end{array}$ \\
\hline Conceitual & $\begin{array}{l}\text { Conteúdo de relevância global atribuído a objetos que representam ocorrências geológicas } \\
\text { singulares e com significado à escala planetária, de que são exemplo os GSSP, locais únicos no } \\
\text { mundo que representam um determinado limite entre intervalos de tempo geológico (andares). } \\
\text { Sua importância está estritamente relacionada às comunidades científicas, que os veem como } \\
\text { marcos geológicos únicos, que representam os acontecimentos mais importantes da história da } \\
\text { Terra. }\end{array}$ \\
\hline
\end{tabular}


No geossítio Ilha Vulcânica de Santo Aleixo foi identificado o conteúdo indicial materializado nas fraturas que indicam contração e resfriamento rápido do magma. O conteúdo simbólico está presente nas diversas atividades que podem ser realizadas na ilha, como o turismo, atividades educativas e científicas, e ainda apresenta valor histórico. São bastante representativos os conteúdos documental, cênico e conceitual associado a Suíte Magmática Ipojuca.

O geossítio Cachoeira da Bulha apresenta conteúdo indicial, que expressa graficamente a queda de blocos ou os processos erosivos que permitiram a formação da cachoeira. Possui ainda valor simbólico, através do turismo e atividades recreativas e educativas. Apresenta um conteúdo cênico relevante.

Nos geossítios Trilha das Geoformas e Estuário e Várzea do Una foi identificado o conteúdo indicial, presente nos processos e formas geomorfológicas. Identificou-se também a presença de outros valores, como turístico, educativo e econômico, que permitem identificar o conteúdo simbólico, bem como o cênico, decorrente da beleza e harmonia da paisagem local.

\section{Valores da Geodiversidade}

A análise qualitativa, com base nos valores propostos por Gray (2004), está fundamentada em seis critérios: intrínseco, cultural, estético, econômico, funcional e científico/educativo. Para facilitar a análise foram feitas 13 fichas contendo seis perguntas diretas para cada geossítio, onde caberiam quatro tipos de respostas: Inexistente, Baixo, Médio ou Alto (Santos, 2012) (Tabela 3).

Os parâmetros utilizados para responder o questionário foram baseados na realidade da região, por exemplo, o valor científico com base em tudo que já foi escrito e publicado na área; o econômico de acordo com turismo e uso atual de cada geossítio; ao cultural foi levado em consideração o contexto histórico e o conhecimento popular e os valores intrínseco, estético e funcional foram determinados por uma compilação de índices como: publicações, observações de campo e opinião de frequentadores da área. Ao analisar os resultados na tabela (Tabela
3) é possível observar que apenas um geossítio apresentou a inexistência de valores, o geossítio Neck Vulcânico da Usina Ipojuca (econômico), isso se dá em função do geossítio estar localizado em uma área privada da usina, sem nenhum incentivo ao turismo ou outra atividade econômica referente a ele.

A economia movida na área está em função da plantação de cana-de-açúcar para indústria sucroalcooleira, o que neste caso não foi levado em consideração como valor econômico por ser uma atividade independente do geossítio. A sugestão seria que a usina unisse $o$ valor científico/educacional representado pelo plug vulcânico ao seu valor histórico e cultural e decidisse assim abrir suas portas para visitação. Com a movimentação de pessoas no local, mesmo que não fosse cobrada entrada para isso, a comunidade que vive nas terras da usina poderia comercializar alguns produtos mesmo que de modo informal.

A classificação "baixa" é observada em quatro geossítios: Banho de Argila de Gaibu (estético e econômico), Rocha Vulcânica Piroclástica do Engenho Saco (cultural e estético), Cachoeira da Bulha (cultural, econômico e científico) e Trilha das Geoformas (econômico). Dez dos geossítios inventariados apresentam algum valor mediano e onze deles obtiveram valor alto em mais de um critério.

Para a Cachoeira da Bulha foi atribuído ao critério estético (cênico) o valor médio, entendendo que há uma constituinte estética para o geossítio, todavia, não com um valor tão elevado em comparação, por exemplo, aos geossítios das Pedras Pretas (alto), Promontório do Cabo (alto), Piscinas Naturais de Porto de Galinhas (alto), Ilha Vulcânica de Santo Aleixo (alto) e os demais que também obtiveram classificação alta neste quesito (Tabela 3).

O conjunto de metodologias mostra que as áreas consideradas complexas apresentam praticamente todos os conteúdos patrimoniais propostos por Pena Reis e Henriques (2009), assim como apresenta de médio a alto os valores da geodiversidade propostos por Gray (2004). 
Revista Brasileira de Geografia Física v.10, n.04 (2017) 1218- 1238.

Tabela 3. Resultado das aplicações das metodologias qualitativas aos geossítios

\begin{tabular}{|c|c|c|c|c|c|c|c|c|c|c|c|c|c|}
\hline \multirow[b]{2}{*}{ GEOSSITIOS } & \multirow[b]{2}{*}{$\begin{array}{c}\text { TIPOLOGI } \\
\mathbf{A} \\
\end{array}$} & \multicolumn{6}{|c|}{ CONTEÚDOS PATRIMONIAIS } & \multicolumn{6}{|c|}{ VALORES DA GEODIVERSIDADE } \\
\hline & & Indicial & Icnográfico & Simbólico & Documental & Cênico & Conceitual & Intrínseco & Cultural & Estético & Econômico & Funcional & $\begin{array}{l}\text { Científico/ } \\
\text { Educativo }\end{array}$ \\
\hline G1 Pedras Pretas & Seção & Sim & Não & Sim & Sim & Sim & Sim & Médio & Médio & Alto & Médio & Alto & Alto \\
\hline $\begin{array}{l}\text { G2 Banho de } \\
\text { Argila }\end{array}$ & Ponto & Não & Não & Sim & Sim & Não & Sim & Médio & Médio & Baixo & Baixo & Médio & Médio \\
\hline $\begin{array}{l}\text { G3 Promontório } \\
\text { do Cabo }\end{array}$ & $\begin{array}{c}\text { Área } \\
\text { complexa }\end{array}$ & Sim & Não & Sim & Sim & Sim & Sim & Alto & Alto & Alto & Alto & Alto & Alto \\
\hline $\begin{array}{l}\text { G4 Neck vulcânico } \\
\text { da Usina Ipojuca }\end{array}$ & Área & Sim & Não & Sim & Sim & Sim & Sim & Alto & Médio & Médio & Inexistente & Alto & Alto \\
\hline $\begin{array}{l}\text { G5 Beachrocks de } \\
\text { Muro Alto }\end{array}$ & Seção & Sim & Não & Sim & Sim & Sim & Não & Médio & Médio & Alto & Alto & Alto & Alto \\
\hline $\begin{array}{c}\text { G6 Rocha } \\
\text { vulcânica } \\
\text { piroclástica do } \\
\text { Engenho Saco } \\
\end{array}$ & Área & Sim & Não & Não & Sim & Não & Sim & Alto & Baixo & Baixo & Alto & Alto & Alto \\
\hline $\begin{array}{c}\text { G7 Piscinas } \\
\text { Naturais de Porto } \\
\text { de Galinhas }\end{array}$ & Área & Sim & Não & Sim & Sim & Sim & Não & Alto & Médio & Alto & Alto & Alto & Alto \\
\hline $\begin{array}{l}\text { G8 Ilha Vulcânica } \\
\text { de Santo Aleixo }\end{array}$ & Área & Sim & Não & Sim & Sim & Sim & Sim & Alto & Médio & Alto & Alto & Alto & Alto \\
\hline $\begin{array}{c}\text { G9 Formas e } \\
\text { Meandros do Rio } \\
\text { Formoso }\end{array}$ & $\begin{array}{c}\text { Área } \\
\text { complexa }\end{array}$ & Sim & Não & Sim & Sim & Sim & Não & Alto & Alto & Alto & Alto & Alto & Alto \\
\hline $\begin{array}{c}\text { G10 Arenitos } \\
\text { algálicos da Praia } \\
\text { dos Carneiros }\end{array}$ & Seção & Sim & Não & Sim & Sim & Sim & Não & Médio & Médio & Alto & Alto & Alto & Alto \\
\hline $\begin{array}{c}\text { G11 Cachoeira da } \\
\text { Bulha }\end{array}$ & Ponto & Sim & Não & Sim & Não & Sim & Não & Médio & Baixo & Médio & Baixo & Médio & Baixo \\
\hline $\begin{array}{l}\text { G12 Trilha das } \\
\text { Geoformas }\end{array}$ & $\begin{array}{c}\text { Área } \\
\text { complexa }\end{array}$ & Sim & Não & Sim & Não & Sim & Não & Médio & Médio & Alto & Baixo & Alto & Médio \\
\hline $\begin{array}{l}\text { G13 Estuário e } \\
\text { Várzea do Una }\end{array}$ & $\begin{array}{c}\text { Área } \\
\text { complexa }\end{array}$ & Sim & Não & Sim & Não & Sim & Não & Alto & Alto & Alto & Médio & Alto & Alto \\
\hline
\end{tabular}


O valor científico dos geossítios também se apresentou de forma significativa e coerente em ambas as análises, assim como o valor de uso, neste caso específico da atividade turística, que movimenta de forma significativa a economia da região. Como dito anteriormente, não foi objetivo desta etapa do trabalho criar um ranking de prioridades e analisá-los de forma quantitativa.

Contudo, a partir das leituras bibliográficas, trabalhos de campo, preenchimento das fichas e análises qualitativas com base nas três propostas mencionadas é possível diferenciar os valores de cada geossítio e destacar os que apresentam um conjunto de valores mais elevados, além de fazer um comparativo entre as três propostas e destacar a coerência da maioria dos resultados.

Vê-se que os valores da geodiversidade que tiveram maior expressão foram funcionais, estéticos e científicos. Estes estão diretamente ligados aos principais critérios e objetivo geral do trabalho que é a geoconservação e o fortalecimento do geoturismo. Este resultado corrobora para a eficiência do tipo de análise, e mesmo havendo subjetividade mostrou-se coerente com relação à realidade vivenciada no campo e estudada nas bibliografias prévias.

\section{Conclusões}

O trabalho de inventariação de uma região não pode ser considerado algo concluído ou definitivo, uma vez que a cada nova visita a campo novos sítios poderão ser descobertos, cabendo assim uma nova inserção ao inventário. Do mesmo modo que, por processos naturais ou mesmo antrópicos, algum geossítio, com uma alta fragilidade ou vulnerabilidade pode deixar de existir, alterando assim, mais uma vez a inventariação.

O inventário dará subsídio a uma próxima etapa de ações a serem trabalhadas neste território, com a aplicação de metodologias apropriadas para a criação de um ranking de prioridades que irá contribuir para o desenvolvimento de estratégias direcionadas a geoconservação do patrimônio geológico e geomorfológico local.

Com base nas análises qualitativas é possível identificar os geossítios com maior relevância científica e educativa, bem como os que já estão inseridos em roteiros turísticos onde a geologia e os processos geomorfológicos são explicitamente os fatores determinantes para o uso destes elementos enquanto produtos turísticos.

Estes resultados ratificam a relevância científica dessa região e dos processos geodinâmicos, que apresentam influência e abrangência global, uma vez que foram comprovados registros geológicos diretamente relacionados a atual configuração dos continentes.

A grande parte dos geossítios descritos, além do caráter científico, apresenta relevante potencial turístico e cultural, que pode, através de projetos de popularização das Geociências, aproximar o público em geral às Ciências da Terra, contribuindo no sentido de difundir o conhecimento geológico e geomorfológico (Popularização das Geociências) e utilizá-lo como subsídio à atividade econômica e desenvolvimento local em áreas costeiras.

No entanto, para que haja de fato investimento neste sentido, é preciso que sejam cumpridas algumas fases no que se refere ao plano de geoconservação nessas áreas, como inventariação e quantificação dos geossítios, análises de riscos e incertezas, diretrizes e estratégias de geoconservação, sensibilização e educação ambiental com as comunidades e público em geral, bem como investimento e participação do poder público.

Este artigo representa uma das etapas de um projeto maior e mais complexo que se justifica diante da excepcionalidade do patrimônio geológico apresentado no Litoral Sul de Pernambuco e a possibilidade de promover desenvolvimento de estratégias de geoconservação, geoturismo e valorização do território.

\section{Agradecimentos}

À Coordenação de Aperfeiçoamento de Pessoal de Nível Superior do Brasil (CAPES) pelo apoio financeiro a esta investigação e à professora Maria Helena Henriques da Universidade de Coimbra - PT, pelas explicações a cerca das análises qualitativas referentes ao valor patrimonial da geodiversidade. Agradecemos ainda ao revisor, pelas valiosas contribuições ao trabalho.

\section{Referências}

Ab'Saber, A.N., 2003. Os domínios de natureza no Brasil: potencialidades paisagísticas, $7 \mathrm{ed}$. Ateliê Editorial, São Paulo.

Arai, M., 2006. A grande elevação eustática do Mioceno e sua influência na origem do Grupo Barreiras. Revista do Instituto de Geociências 6, 1-6.

Barbosa, B.M.A., 2009. Mapeamento Geológico do Plúton Rio Formoso e da Formação Cabo Bacia de Pernambuco, no município de Rio Formoso, Estado de Pernambuco. Relatório de Graduação. Recife, UFPE. 
Barreto, A.M.F., Assis, H.M.B., Bezerra, F.H.R., Suguio, K., 2010. Arrecifes, a Calçada do Mar de Recife, PE - Importante registro holocênico de nível relativo do mar acima do atual, in: Winge, M., Schobbenhaus, C., Souza, C.R.G., Fernandes, A.C.S., Berbert-Born, M., Sallun filho, W., Queiroz, E.T. (Eds.), Sítios Geológicos e Paleontológicos do Brasil. Disponível:

http://sigep.cprm.gov.br/sitio040/sitio040.pdf. Acesso: 13 set. 2015.

Branner, J.C., 1904. The stone reefs of Brazil their geological and geographical relations with a chapter on the coral reefs. Bulletin of the Museum of Comparative Zoology 44. Harvard College, Cambridge.

BRASIL, 1981. Lei no 6938, de 31 de agosto.

BRASIL, 1988. Lei $\mathrm{n}^{\circ} 7661$, de 16 de maio.

Brilha, J., 2005. Patrimônio Geológico e Geoconservação: A Conservação da Natureza na sua Vertente Geológica. Palimage Editores, Braga

Brilha, J., 2015. Inventory and quantitative assessment of geosites and geodiversity sites: a review. Geoheritage 8, 119-134.

Brito Neves, B.B., 1975. Regionalização tectônica do Pré-Cambriano Nordestino. Tese (Doutorado). São Paulo, USP.

Darwin, C., 1841. On a remarcable bar of sandstone of Pernambuco on the coast of Brazil. Magazin \& Journal Sciences 19, 257-261.

CPRM. Serviço Geológico do Brasil, 2005. Projeto cadastro de fontes de abastecimento por água subterrânea. Diagnóstico do município de São José da Coroa Grande, Estado de PE. Recife.

Fuertes-Gutiérrez, I., Fernández-Martínez, E., 2010. Geosites inventory in the Leon Province (Northwestern Spain): a tool to introduce geoheritage into regional environmental management. Geoheritage 2, 57-75.

García-Cortés, Á., Carcavilla, L., Díaz-Martínez E., Vegas, J., 2014. Documento metodológico para la elaboración del inventario español de lugares de interés geológico (IELIG). Disponível:

http://www.igme.es/patrimonio/novedades/ME TODOLOGIA\%20IELIG\%20V16\%20Web.pd f. Acesso: 15 jun. 2015.

García-Cortés, A., Carcavilla Urquí, L., 2009. Documento metodológico para la elaboración del inventario español de lugares de interés geológico (IELIG), version 12. Instituto Geológico y Minero de España, Madrid.

Gray, M., 2004. Geodiversity: valuing and conserving abiotic nature. John Wiley and Sons, Chichester, England.
Guimarães, T.O., Mariano, G., Sá, A.A., 2016. Beachrocks of Southern Coastal Zone of the State of Pernambuco (Northeastern Brazil): Geological Resistance with History. Geoheritage. doi:10.1007/s12371-016-0181-4.

Henriques, Mh., Pena Dos Reis, R., Brilha, J., Mota, TS., 2011. Geoconservation as an emerging geoscience. Geoheritage 3, 117-128.

Henriques, Mh., Pena Dos Reis, R., 2015. Framing the Palaeontological Heritage Within the Geological Heritage: An Integrative Vision. Geoheritage, DOI 10.1007/s12371-014-0141-9

Lima, F.F., 2008. Proposta Metodológica para a Inventariação do Património Geológico Brasileiro. Dissertação (Mestrado). Braga, Universidade do Minho.

Lima, F.F., Brilha, J.B.R., Salamuni, E., 2010. Inventorying geological heritage in large territories: a methodological proposal applied to Brazil. Geoheritage, 2, 91-99.

Lima Filho, M., 1998. Análise Estratigráfica e Estrutural da Bacia Pernambuco. Tese (Doutorado). São Paulo, USP.

Lima Filho, M., Barbosa, J.A., Souza, E.M., 2006. Eventos tectônicos e sedimentares nas bacias de Pernambuco e da Paraíba: implicações no quebramento do Gondwana e correlação com a bacia do rio muni. Geociências 25, 117-126.

Long, L.E., Sial, A.N., Ekvanil, H.E., Borba, G.S., 1986. Origin of granite at Cabo de Santo Agostinho - Northeast - Brasil. Contributions to mineralogy and petrology 92, 341-350.

Mabesoone, J.M., 1964. Origin and age of the sandstone reefs of Pernambuco (Northeastern Brazil). Journal of Sedimentary Petrology, 34, 1-7.

Mabesoone, J.M., Alheiros, M.M., 1988. Origem da bacia Sedimentar Costeira PernambucoParaíba. Revista Brasileira de Geociências 18, 476-482.

Mabesoone, J.M. (Coord.), 1987. Revisão geológica da faixa sedimentar costeira de Pernambuco, Paraíba e Rio Grande do Norte, e do seu embasamento. UFPE-FINEP / PADCT, Recife.

Maia, M.F.B., 2012. Revisão da estratigrafia Aptiano-Albiano da Bacia de Pernambuco, Nordeste do Brasil. Dissertação (Mestrado). Recife, UFPE.

Maia, M.F.B., Barbosa, J.A., Lima Filho, M., Mort, H.P., Santana, R., 2012. Características petrográficas e geoquímicas das formações siliciclásticas (aptiano-albiano) da Bacia de Pernambuco, NE do Brasil. Estudos Geológicos 22, 55-75.

Mauz, B., Vacchi, M., Green, A., Hoffmann, G., Cooper, A., 2015. Beachrock: A tool for 
reconstructing relative sea level in the far-field. Marine Geology 362, 1-16.

Melo Neto, U.P., 1981. O Cabo de Santo Agostinho e a Baía de Suape. Revista do Instituto Arqueológico, Histórico e Geográfico Pernambucano 13, 1-38.

Miles, M.B, Huberman, AM, Saldaña, J., 2014. Qualitative data analysis: a methods sourcebook, 3 ed. Arizona State University, Tempe.

Moreira, F.M., Santos, A.S., Melo, C.R., Almeida, I.S.E., Araújo, L.M.N., 2003. Hidrologia, in: PFALTZGRAFF, P. A. S. (Coord.). Sistema de Informações Geoambientais da Região Metropolitana do Recife. CPRM, Recife.

Nascimento, M.L., Valença, R.F.E., Wildner, W., 2012. Litoral Sul de Pernambuco (PE), in: Schobbenhaus C., Silva C.R. Geoparques do Brasil: propostas. CPRM, Rio de Janeiro.

Nascimento, M.A.L., 2003. Geologia, geocronologia, geoquímica e petrogênese das rochas ígneas cretácicas da província magmática do Cabo e suas relações com as com as unidades sedimentares da Bacia de Pernambuco (NE do Brasil). Tese (Doutorado). Natal, UFRN.

Neumann, V.H., Valença, L.M.M., Barreto, A.M.F., Barbosa, J.A., 2003. Beachrocks da Praia dos Carneiros, próximos à desembocadura do rio formoso, Tamandaré - PE: arenitos de praia com intercalações da alga codiácea do gênero Halimeda. II Congresso sobre Planejamento e Gestão das Zonas Costeiras dos Países de Expressão Portuguesa, IX Congresso da Associação Brasileira de Estudos do Quaternário e II Congresso do Quaternário dos Países de Línguas Ibéricas.

Ottmann, F., 1960. Une hypothese sur l'origine des arrecifes du Nordeste brésilien. Comptes Rendus Somaires des Séances de la Société Geologique de France 7, 175-176.

Pena dos Reis, R., Henriques, M.H., 2009. Approaching an Integrated qualification and evaluation systen for geological heritage. Geoheritage, 1, 1-10.

Pereira, P.M.N., 2011. Bernardo Ramires Esquível (1723-1812). Aristocracia e ofício nos finais do antigo regime. Dissertação (Mestrado). Lisboa, Faculdade de Letras.

Pereira, R.G.F.A., 2010. Geoconservação e Desenvolvimento Sustentável na Chapada Diamantina (Bahia - Brasil). Tese (Doutorado). Braga, Universidade do Minho.

Pfaltzgraff, P.A.F., 2007. Mapa de suscetibilidade a deslizamentos na Região Metropolitana do Recife. Tese (Doutorado). Recife, UFPE.
ProGEO, 2002. Patrimônio geológico português: proposta de classificação. Disponível: <http://www.progeo.pt/pdfs/invent.pdf. Acesso: 15 mai. 2015.

Rocha, D.M.T., 2008. Inventariação, caracterização e avaliação do patrimônio geológico do concelho de Arouca. Tese (Mestrado). Braga, Universidade do Minho.

Rossetti, D. F., Góes, A. M., 2009. Marine influence in the Barreiras Formation, state of Alagoas, northeastern Brazil. Anais da Academia Brasileira de Ciências 81, 741-755.

Sial, A.N., 1976. The Post-Paleozoic Volcanism of Northeast Brazil and its Tectonic Significance. An. Academia Brasileira de Ciências 48, 299311.

Silva Filho, A.F., Guimarães, I.P., Van Schmus, W.R., 2002. Crustal evolution of the Pernambuco - Alagoas complex, Borborema province, NE Brazil: Nd isotopic data from neoproterozoic granitoids. Gondwana Reserarch 5, 409-422.

Suguio, K., Barreto, A.M.F., Oliveira, P.E., Bezerra, F.H.R., Vilela, M.C.S.H., 2013. Indicadores de variações holocênicas do nível do mar ao longo da costa dos Estados de Pernambuco e Paraíba, Brasil. Revista do Instituto de Geociências 3, 14-152.

Suguio, K., Martin, L., Bittencourt, A.C.S.P., Dominguez, J.M.L., Flexo, J.M., Azevedo, A.E.G., 1985. Flutuações do nível relativo do mar durante o Quaternário Superior ao longo do litoral brasileiro e suas implicações na sedimentação costeira. Revista Brasileira de Geociências 15, 273-286.

Theodorson, G.A., Theodorson, A.G., 1970. A modern dictionary of sociology. Methuen, London.

Uceda, A.C., 2000. Patrimonio geológico, diagnóstico, clasificación y valoración, in: Palacio, J. (Coord.), Jornadas sobre Património Geológico y Desarrollo Sostenible. Ministerio de Medio Ambiente, Madrid, pp. 23-37.

Uceda, A.C., 1996. El Patrimonio Geológico. Ideas para su protección, conservación y Utilización, in: MOPTMA, El Patrimonio Geológico: Bases para su valoración, protección, conservación y utilización. Madrid, pp. 17-27.

UNESCO. United Nations Educational, Scientific and Cultural Organization, 2014. Convenção para a proteção do patrimônio mundial, cultural e natural. Disponível: http://whc.unesco.org/archive/conventionpt.pdf. Acesso: 09 set. 2014.

Wimbledon, W.A.P., Ishchenko, A.A., Gerasimenko, N.P., Karis, L.O., Suominen, V., Johansson, C.E., Freden, C., 2000. Geosites - 
Revista Brasileira de Geografia Física v.10, n.04 (2017) 1218- 1238.

An IUGS initiative: science supported by conservation, in: Barettino, D., Wimbledon, W.A.P., Gallego, E. (Eds.), Geological Heritage: its conservation and management. IGME, Madrid, pp. 69-94.
Wimblendon, W.A.P., Smith-Meier, S., 2012. Geoheritage in Europe and its conservation. ProGEO. 